\title{
The Effectiveness of Learning Using Social Media during the Covid 19 Pandemic in Higher Education
}

\author{
Ismail Hanif Batubara ${ }^{1}$, Kholidah Nur ${ }^{2}$, Ali Topan Lubis ${ }^{3}$, Nanang Arianto ${ }^{4}$ \\ ${ }^{1}$ Universitas Muhammadiyah Sumatera Utara, Indonesia \\ ${ }^{2,3,4}$ Sekolah Tinggi Agama Islam Negeri Madina, Indonesia \\ ismailhanif@umsu.ac.id, alitopanlubis@stain-madina.ac.id,nanangarianto@stain-madina.ac.id
}

\begin{abstract}
This study explains the factual about learning using online media during long-distance lectures during the Covid 19 epidemic. Some students are used as a source of information using a qualitative approach method. By using behaviorism and cognitive theory. Online Distance Learning can take advantage of social media with virtual online learning via video conferencing, teleconferences, in groups on social media. Social media is a way out to get rid of boredom or stress from studying at home. These are new conditions for faculty and students, Makathe role of lecturers is very much needed in managing or managing learning starting from planning, organizing, actuating and evaluating in order to increase the effectiveness of the teaching and learning process during the COVID-19 pandemic.
\end{abstract}

Keywords

learning, social media;

covid 19

\section{Introduction}

Education is one way to produce quality Human Resources (HR) with experience changes in knowledge, skills and attitudes. These changes can be a capital to improve selfcompetence in facing the era of globalization that always undergoes the change (Sitorus et al, 2019). Starting from the beginning of 2020, the world was shocked by the outbreak of the Corona virus (COVID-19) which has infected almost all countries in the world. Since January 2020, WHO has declared the world entered into a global emergency related to this virus. The corona virus that attacks the respiratory system has recorded more than 28 million cases from 213 infected countries in the world. Quoted by Pikiran-Rakyat.com from the Worldo Meters page, as of Sunday, September 13, 2020, the total number to be precise has reached 28,916,010 positive cases of COVID-19 globally. The global epidemic has hit the world, as has happened in Indonesia, so the stay at home program was implemented as an effort to suppress the expansion of Covid-19 (Zahrotunni'mah, 2020: 248). To comply with government programs, the learning model is transferred to virtual classrooms, so that students still get their right to gain knowledge but are still safe at home. Buana (2020) explains the steps that have been taken by the government to be able to solve this extraordinary case, one of which is by socializing the social distancing movement.

Circular number 4 of 2020 concerning the implementation of educational policies in the emergency period of the spread of Coronavirus Disease (Covid-19) the learning process from home is carried out with the following conditions: Learning from home through online / distance learning is carried out to provide meaningful learning experiences for students, without being burdened with demands to complete all curriculum achievements for class promotion and graduation. Learning from home can be focused on life skills education, among others, regarding this pandemic, Arizona (2020: 66). Learning from home activities and assignments may vary between students, according to their 
respective interests and conditions, including considering access / learning facilities at home. Evidence or products of learning activities from home are given qualitative and useful feedback from the lecturer, without being required to give a quantitative score. There are many benefits when studying online / distance during this pandemic, one of which is that we can study anytime and anywhere which will provide comfort for those of us who are studying online / distance.

In order to increase awareness and prevention of corona virus transmission on campus. The lecturers also have assignments, for example preparing teaching materials to be uploaded to students, determining learning media such as Whatsapp groups, Email, Google Clasroom, or other learning media applications according to the recommendations of the Ministry of Religion and the Ministry of Education and Culture. Parents are also asked to ensure students carry out learning activities at their respective homes, limit permits for activities outside the home, coordinate with lecturers or campuses, help students implement a clean and healthy lifestyle (PHBS) at home and so on. Students are asked to study material or subject matter uploaded by lecturers through the agreed media.

There are quite a lot of choices for online learning applications that can be applied in the world of education. One of the free and familiar applications implemented is the Google Classroom application. Teachers, lecturers, tutors and instructors in general can open classes and invite students to the class. Online learning in the application can take place with various materials and assignments given by teachers to students. Teachers can also provide grades related to assignments that are collected neatly and well archived. The online learning that is applied allows teachers and students to carry out learning without going through face-to-face in the classroom by providing learning material (in the form of power point slides, e-books, learning videos etc., assignments (independent or group), as well as assessment. (Silalahi et al, 2020)

However, the parents now have a heavy burden. A quite heavy adjustment will actually occur at home, especially parents in accompanying and supervising children when they participate in the learning process at home by giving the understanding that they must continue to study as usual. Writing this article aims to provide a literarure review that will focus on the concept of distance learning through the online campus method and the important role of parental supervision in implementing online campuses during the Covid19 pandemic. This condition requires educational institutions to innovate in the learning process. One form of innovation is by learning online or online (Jamaluddin, D., Ratnasih, T., Gunawan, H., \& Paujiah, E. (2020).

However, in online learning this is inseparable from the problems that become obstacles in its implementation, including online learning for students at educational institutions in higher education. Therefore, various solutions are needed as a solution as well as steps to be taken in the future as projections. Obstacles, solutions and projections of online learning for prospective lecturers are important to know, considering that this learning system is used by lecturers as an institution that produces prospective workers, as a result of an extraordinary event, namely the Covid-19 outbreak.

\section{Research Methods}

Behavioristic theory is a theory that discusses changes in a person's behavior based on a new experience. Behavioristic theory emphasizes the formation of behavior that can be seen from the results of the learning process during the COVID-19 pandemic. Likewise in this study using cognitive theory, namely individual behavior can be directed through new situations, such as learning with online models. Simultaneously with having a 
relationship with the purpose of the procession. Because, in the dynamic nature of student behavior it affects the effectiveness of the teaching and learning process.

This research was conducted using a descriptive method with a qualitative approach and literature study. Qualitative research is used by referring to the opinion of Sugiyono, 2009: 2), that the qualitative research method is a naturalistic research method because the research is carried out in natural conditions (natural setting), and the data collected is analyzed qualitatively.(Miles, MB, \& Huberman, M., 1994). The research instrument consisted of an interview guide conducted via telephone and online media via the WhatsApp application. This research was conducted in 2020. The research method we carried out was a qualitative research method. Approaches or tracing to explore and understand a central phenomenon. The data collection technique that we do is using google form. We also use this google form because it is faster and more extensive for distributing questionnaires to students. On the other hand, because of this social distancing policy, it is not possible if we use the direct interview method.

\section{Results and Discussion}

In learning interactions, it is strongly influenced by several components, namely: students, lecturers, head of campus, curriculum, campus (library) facilities, and several other facilities needed in the learning process so that they will support the quality of learning1 Thus, learning activities can bring changes to participants students, both changes in knowledge, behavior, and skills. With these changes, of course students will be trained in solving life's problems and can adapt to their environment. There are 2 (two) approaches to Distance Learning (PJJ) which include online distance learning and offline learning.

Learning management has a very important position in order to increase the effectiveness of the teaching and learning process, especially in the emergency period of the spread of Corona Virus Disease-19 (COVID-19) as we are experiencing today. Various attempts were made to improve the quality of education while still considering health protocols in accordance with the Ministerial Decree 4. Various obstacles, difficulties, and limitations faced in the teaching and learning process, starting from the factors of students, the families of students, as well as less representative facilities and infrastructure. There is a limitation of the student factor on the grounds that the internet package has run out. Parents complained a lot about having to buy a package by installing an indihome at their house (Interview with students and parents).

Utilizing this information technology can act as a medium that provides between students and lecturers, learning resources and means for efficient evaluation of learning. When conducting interviews with students, with online learning online, students get the latest information by accessing the zoom application to be able to meet directly with colleagues from their respective areas (interviews with students in several universities). According to Bell et al., (2017) online learning allows interaction via the web even though they are in far and different places (Arzayeva, et al., 2015). The advantage of using online learning is that learning is independent and high interactivity, can increase memory levels, provide a more learning experience, with text, audio, video and animation.(Oknisih, N., \& Suyoto, S., 2019). SAll of them are used to convey information, and also make it easy to convey, update content, download, students can also send e-mails to other students, post comments on discussion forums, use chat rooms, to videoconference links to communicate directly. The online learning model is the first choice, namely as many as $100 \%$ of lecturers use WA facilities or often known as WhatsApps, where lecturers create WhatsApps groups so that all students can be involved in the group. Tasks are given via 
WhatsApps. Even if students still don't understand, the lecturer will also add by sending videos or doing WhatsApps Video Calls with students. (Kim, Wang, \& Oh, 2016).

Assigning assignments makes it easier for students via WhatsApps messages. Assignments can also be sent via WhatsApps and usually students take photos of the assignment and send it to the lecturer. Many of the tutorial videos made by lecturers have also been uploaded via WhatsApps. The way students do assignments is by doing assignments manually by writing in books then photos of the results of the assignments are sent via WhatsApps chat. In an effort to strengthen the assessment, the lecturer also added assignments in the form of a Google Form. The use of WhatsApps is used by lecturers as a means to collect assignments. The reason for the lecturer choosing to use WA is that it is more practical, easier for children to understand, more effective because it does not require a lot of quotas in the learning process. Another reason is that it is easier and all the parents of student guardians can use it and it is not a foreign thing. Currently WA is easier and can be reached by many groups. The advantage of using WA is that it is easier to operate and easier in sending questions and materials. Even if you want to have a virtual meeting, the lecturer can directly use the WA Video Call feature. WA is simple, effective and efficient in its use.

Online learning activities run well and fun even though there is an obstacle in using the Zoom application, namely the situation and conditions of the home environment or network (signal), it can hinder students with slow internet connection, but if there is unclear information the lecturer will repeat his explanation until students understand the material provided by the lecturer. For Google Classroom, I use it to share information related to my courses and for Zoom I use it for discussions and student absences.

Online learning is learning that is carried out using an internet connection as a liaison for communication between educators and students without any physical contact. Online learning has several weaknesses, namely the use of the internet network requires adequate infrastructure, requires a lot of money, communication via the internet has various obstacles / lags. Besides that, there are also advantages which include the level of interaction between students and lecturers, learning can be done anywhere and anytime (time and place flexibility), Reaching students in a broad scope (potential to reach a global audience), and making it easier for improvement. and storage of learning materials (easy updating of content as well as archivable capabilities.

Difficulties arise not only in terms of skills in using technology, but also related to the large workload considering that there are many courses that must be faced in this era of the COVID-19 pandemic. This happens because students are accustomed to regular faceto-face learning, whereas previous distance learning was only done incidentally. So that this change in learning patterns presents its own problems for students. the emergence of pressure and stress on students doing distance learning. At this point, the pressure certainly feels heavier, so that students do a lot of coping stress, one of which is engaging with the use of social media. So at this point, social media should be a way out to get rid of boredom or stress from studying at home. It's just that things are different during the COVID-19 pandemic. Information overload has been shown to cause social media fatigue by overloading individual cognition.

At the implementation level of PJJ, educational units are welcome to apply (online or offline or the convergence of both) based on the readiness and ability of educational institutions. Online Distance Learning facilities and infrastructure can utilize gadgets and laptops through several portals and online learning applications. The online learning process consists of: first; Virtual face-to-face via video conferencing, teleconferences, and / or group discussions on social media or messaging applications. In this case, educators 
and students can interact directly. Second; Learning Management System (LMS). LMS is an online integrated learning management system through an application.

Learning activities in the LMS include registration and account management, mastery of material, completion of assignments, monitoring of learning outcomes, engaging in discussion forums, consultations and examinations / assessments. Examples of LMS include virtual learning house class, google classroom, edmodo, moodle, zenius lecturer room, seamolec LMS teacher, and so on. Meanwhile, Offline Learning can use books, modules and teaching materials in the environment around the institution and so on. Online and offline learning time throughout the day adjusts to the availability of time, conditions, andEducators exercise control over the programs they compose themselves, whether in accordance with what they set.

Supervision includes supervision, and assesses the implementation of standards and supports the achievement of learning objectives. If there is an error or there is a program that does not meet the target, it is immediately revised in the plan, so that the predetermined objectives can be maximally achieved.Supervision activities are carried out by educators in order to find information, analyze information, and evaluate data related to learning activities and use them to control learning activities to achieve learning targets. Improvement is carried out during the teaching and learning process and also in the subsequent learning process as part of the learning control applied by the educator. In addition to monitoring or evaluating learning programs, educators also supervise the achievement of students' competencies. Supervision of the achievement of student competencies is carried out with adjustments to the provisions of emergency conditions.

This process runs on a scale that has never been measured and tested because it has never happened before. Inevitably, remote villages with very dense campus age become confused, because the information technology infrastructure is very limited. Student assessments move online and there is a lot of trial and error with an unpredictable system, in fact many assessments have been canceled. The second is the long-term impact. Many community groups in Indonesia will be exposed to the long-term impact of Covid-19. The long-term impact of education is an aspect of justice and an increase in inequality between community groups and between regions in Indonesia.

The condition of lecturers in Indonesia does not fully understand the use of technology, this can be seen from lecturers who were born in the year before the 1980s. Information technology constraints limit their use of online media. Likewise with students whose conditions are almost the same as lecturers, which is meant by understanding the use of technology. Tech support devices are obviously expensive. Many in Indonesia are lecturers who are still in dire economic condition. The welfare of lecturers and students has prevented them from being completely limited in enjoying the information technology facilities and infrastructure that were very much needed by the Covid-19 disaster. The internet network is still uneven in all corners of the country. Not all educational institutions, both primary and secondary campuses, can enjoy the internet.

Costs are also an obstacle because aspects of the welfare of lecturers and students are still far from expectations. When they use their internet quota to meet their online media needs, it is clear that they cannot afford to pay for it. (Naserly, MK, 2020). There is a dilemma in the use of online media, when the minister of education encourages productivity to move forward, but on the other hand the financial skills and abilities of lecturers and students have not moved in the same direction. The state has not been fully present in facilitating the financial needs in question. Online learning requires facilitation such as smartphones or laptops, but there are some students who do not have a smartphone 
or laptop plus the absence of internet quota to carry out online learning is a big problem for lecturers and students.

In addition, with online learning, lecturers also become overwhelmed in applying what methods will be conveyed in online learning so that students understand the material presented because online learning is carried out not face to face. Online learning is not effective because there are reasons for students who do not have a network, no devices such as cellphones or laptops. Therefore, lecturers have difficulties in carrying out this online learning process. Every student really wants to learn calmly and be easily understood in the online learning process. However, lecturers also became confused about how online learning could be carried out without any obstacles and did not become a burden for students.

There are obstacles for lecturers in conducting online learning to students, including the lack of understanding of students when carrying out the online learning process. This is because students do not understand the learning taught by lecturers because they do not meet face to face and lecturers find it difficult to monitor student learning progress. The main factor that is even more important is the lack of facilities owned by students when studying online because not all students have computers or smartphones as learning media using online. Apart from that, another factor is the internet package which cannot be reached by all students.

\section{Conclusion}

The period of the Covid-19 pandemic may be different because the habit of teaching lecturers is always face-to-face in class, now lecturers teach via online / long distance. Online learning is learning that is carried out using an internet connection as a liaison for communication between educators and students without any physical contact.Online Distance Learning can take advantage of devices (gadgets) and laptops through several portals and online learning applications. The online learning process consists of: first; Virtual face-to-face via video conferencing, teleconferences, and / or group discussions on social media or messaging applications.. social media is a way out to get rid of boredom or stress from studying at home. In line with the behavioristic theory, there are changes in the behavior of students and lecturers based on a new phenomenon. Behavior that can be seen from the results of the learning process during the COVID-19 pandemic. Cognitive theory, namely individual behavior can be directed through new situations, such as learning with online models.

This process runs on a scale that has never been measured and tested because it has never happened before. It is inevitable that remote villages with small populations are confused, because the information technology infrastructure is very limited. Likewise, when studying at the campus, the lecturer delivers material directly in class, explains in detail the material from beginning to end, and can directly monitor the level of student understanding of the material presented. So the internal assessment for the campus is considered urgent for student families. Assessment information is very important. Some think that the loss of student assessment information is very meaningful for the sustainability of the student's future. For example, students who have been able to master a lot of skills this year but did not receive the appropriate assessment this year, so that it will have an impact on treatment for the coming year. Another case for students in college. Many tertiary institutions abroad have replaced traditional exams with online tools. This is a new condition for lecturers and students. 
Therefore, the role of lecturers is needed in managing or managing learning starting from planning, organizing, actuating and evaluating in order to increase the effectiveness of the teaching and learning process during the current COVID-19 pandemic, both the implementation of distance learning in the network (online) and outside the network (offline). Therefore, lecturers must be able to use methods and approaches as well as use appropriate facilities and infrastructure so that the teaching and learning process becomes interesting and enjoyable. Provide the widest possible space for students to be creative and actively involved throughout the learning process. Until the cognitive, affective and psychomotor domains students can grow and develop optimally and simultaneously without experiencing stunting.

\section{References}

Arzayeva, M., Rakhimzhanov, K., Abdrahmanova, A., \& Umitkaliev, U. (2015). Special aspects of distance learning in educational system. Anthropologist, 22(3), 449-454. https://doi.org/10.1080/09720073.2015.11891900

Arizona, Kurniawan. et.all. (2020). Pembelajaran Online Berbasis Proyek Salah Satu Solusi Kegiatan Belajar Mengajar di Tengah Pandemi Covid-19 . Jurnal Ilmiah Profesi Pendidikan. Volume 5 No 1 Mei 2020. (Online) :https://jipp.unram.ac.id/index.php/jipp/article/download/111/99. DOI: 10.29303/jipp.v5i1.111

Jamaluddin, D., Ratnasih, T., Gunawan, H., \& Paujiah, E. (2020). Pembelajaran daring masa pandemik Covid-19 pada calon dosen: hambatan, solusi dan proyeksi. LP2M.

Kim, Y., Wang, Y., \& Oh, J. (2016). Digital Media Use and Social Engagement: How Social Media and Smartphone Use Influence Social Activities of College Students. Cyberpsychology, Behavior, and Social Networking. https://doi.org/10.1089/cyber.2015.0408

Miles, M. B., \& Huberman, M. (1994). Qualitative Data Analysis Second Edition. SAGE Publications.

Naserly, M. K. (2020). Implementasi Zoom, Google Classroom, Dan Whatsapp Group Dalam Mendukung Pembelajaran Daring (Online) Pada Mata Kuliah Bahasa Inggris Lanjut (Studi Kasus Pada 2 Kelas Semester 2, Jurusan Administrasi Bisnis, Fakultas Ekonomi dan Bisnis, Universitas Bina Sa. Aksara Public, 4(2), 155-165.

Oknisih, N., \& Suyoto, S. (2019). Penggunaan Aplen (Aplikasi Online) Sebagai Upaya Kemandirian Belajar Siswa. In Seminar Nasional Pendidikan Dasar (Vol. 1, No. 01)

Silalahi, T. et al. (2020). The Application of Cooperative Learning Model during Online Learning in the Pandemic Period. Budapest International Research and Critics Institute-Journal (BIRCI-Journal). P. 1683-1691.

Sitorus, H.V., et al (2019). The Effect of Learning Strategy and Thinking Ability on the Students' Learning Outcomes in Economics Subject of XI Social Students in Senior High School State 1 in Pematang Siantar. Budapest International Research and Critics in Linguistics and Education (BirLE) Journal. P. 451-460.

Zahrotunni'mah. (2020). Langkah Taktis Pemerintah Daerah Dalam Pencegahan Penyebaran Virus Corona COVID-19 di Indonesia. Jurnal Sosial dan Budaya Syar'i Vol. 7 No. 3 (2020), pp.247-260, DOI: 10.15408/sjsbs.v7i3.15103. 